\title{
A HISTOPATHOLOGICAL STUDY OF OVARIAN LESIONS
}

\author{
Ashok Kagathur Puttaveerachary¹, Nanjunda Swamy Doddaiah², Abhishek M. Govindshetty³, Sanjay Manchaiah4 \\ ${ }^{1}$ Assistant Professor, Department of Pathology, Gadag Institute of Medical Sciences, Mallasamudra, Gadag, Karnataka. \\ ${ }^{2}$ Assistant Professor, Department of Pathology, Adichunchanagiri Institute of Medical Sciences, B. G. Nagara, Nagamangala Taluk, \\ Mandya, Karnataka. \\ ${ }^{3}$ Associate Professor, Department of Pathology, Adichunchanagiri Institute of Medical Sciences, B. G. Nagara, Nagamangala Taluk, \\ Mandya, Karnataka. \\ ${ }^{4}$ Associate Professor, Department of Pathology, Adichunchanagiri Institute of Medical Sciences, B. G. Nagara, Nagamangala Taluk, \\ Mandya, Karnataka.
}

\section{ABSTRACT}

\section{BACKGROUND}

Tumours of the ovary are common and form the third most common tumours of female genital tract next to carcinoma cervix and endometrium. Patients usually present at an advanced stage and pose difficulties to clinician as lab workup has limited role. A histopathological study is a must for final diagnosis.

The study was conducted with an aim to find the incidence of non-neoplastic and neoplastic lesions of the ovary with respect to age, reproductive period, use of OCPs and laterality. An attempt was made to study the histopathological diagnosis of the nature of the non-neoplastic lesion and in case of neoplastic lesions their origin and benign or malignant nature. Also, the prognosis in case of malignant lesions was assessed by considering the microscopic grading.

\section{MATERIALS AND METHODS}

This was a descriptive study over 18 months' duration. All surgically resected ovarian specimens were received. Relevant data like history of OCP and laterality of lesion were recorded. They were grossed, processed, examined and categorised as non-neoplastic and neoplastic lesion.

\section{RESULTS}

Out of 148 ovarian lesions studied, 98 were non-neoplastic and 50 were neoplastic. Among non-neoplastic lesions follicular cysts were common, reduction in luteal cysts were noted. Among neoplastic lesions, benign were common. On grading the six malignant lesions, five were grade 1 and one case was grade 3.

\section{CONCLUSION}

Non-neoplastic and benign lesions overshadow the malignant ovarian tumours. However, nonspecific symptomatology in malignant tumours of ovary portends a need for early detection and surgical intervention for better outcome.

\section{KEYWORDS}

Non-neoplastic, Histopathology, OCPs, Grading.

HOW TO CITE THIS ARTICLE: Puttaveerachary AK, Doddaiah NS, Govindshetty AM, et al. A histopathological study of ovarian lesions. J. Evolution Med. Dent. Sci. 2017;6(70):4987-4990, DOI: 10.14260/Jemds/2017/1083

\section{BACKGROUND}

The ovaries constitute the internal reproductive organs, which lie on either side of uterus close to lateral pelvic wall. Normal ovary varies in size, measuring upto $5 \times 3 \times 3 \mathrm{~cm}$. Variation results from endogenous hormonal production, which varies with age and each menstrual cycle.[1]

Although, ovaries are remarkably resistant to diseases, tumours of ovary are common. About $2 / 3^{\text {rd }}$ of ovarian tumours were encountered during reproductive years; $80 \%$ $85 \%$ of them are benign occurring in women between 20 and 44 years of age.[2,3] There are less known facts about the aetiology of ovarian tumours.

Financial or Other, Competing Interest: None.

Submission 10-08-2017, Peer Review 24-08-2017,

Acceptance 26-08-2017, Published 31-08-2017.

Corresponding Author:

Dr. Nanjunda Swamy Doddaiah,

Assistant Professor of Pathology,

Adichunchanagiri Institute of Medical Sciences,

B. G. Nagara-571448,

Nagamangala Taluk

Mandya, Karnataka.

E-mail: swamydn123@gmail.com

DOI: $10.14260 /$ jemds $/ 2017 / 1083$
A few risk factors include nulliparity heredity and few genetic syndromes like Lynch syndrome and Peutz-Jeghers syndrome.[4]

The tumours are asymptomatic in majority of conditions, hence are noticed when tumours grow sufficiently to cause abdominal discomfort and distension. Menstrual irregularities may be present.[5] Benign lesions occur at any age, but more common in reproductive age group. But malignant lesions come towards menopausal 50 - 60 years' age group and then decline.[6]

Even in the era of advanced diagnostic modalities, lab workup has a limited role before surgery. USG can help in defining morphologic characteristics, but cannot differentiate hydrosalpinx paraovarian and tubal cysts.[7] Even diagnostic laparoscopy may miss an intraovarian malignancy. ${ }^{[8]}$

The definitive diagnosis of all ovarian cysts is made histologically.[9] The prognosis of benign cysts is excellent compared to malignant ovarian carcinoma. Most germ cell tumours if diagnosed in early stage has good outcome.[10] So this study has been taken up to find incidence of nonneoplastic and neoplastic lesions and to assess the prognosis considering the microscopic features. 


\section{MATERIALS AND METHODS}

This was a descriptive study conducted over a duration of 18 months from October 2013 to March 2015. The study material included all the hysterectomy and oophorectomy specimens submitted from all the units of OBG Department, and also from other peripheral hospitals to the Department of Pathology. Relevant clinical data was recorded in the case history chart.

148 ovarian masses specimens were subjected for histopathological examination. Ovarian masses were measured and appearance of external surface was noted. Then they were bivalved, nature of the fluid in cystic masses was noted. They were fixed in $10 \%$ formalin overnight. Grossing was done the next day, three sections of cyst wall were taken with emphasis on the thickened area or from the area with papillary excrescences, and in case of solid tumours one section for each centimetre of tumour was taken. A section of non-neoplastic ovary was also taken.

Sections were submitted for processing, slides were made with $5 \mu \mathrm{m}$ thickness of tissues and stained with haematoxylin and eosin. The microscopic features were analysed. The cases were diagnosed and classified according to WHO classification of ovarian tumours.

\section{RESULTS}

Out of total 148 cases 98 were non-neoplastic (66.22\%), while 50 were neoplastic (33.78\%).

Out of 50 neoplastic lesions 42 were benign (84\%), 2 were borderline (4\%) and 6 were malignant (12\%).

\section{Distribution of Ovarian Lesions in Different Age Groups}

Maximum lesions were seen in the age group of 31 to 50 years and least in 61 to 70 years' age group. Non-neoplastic lesions were more in the age group of 31 to 50 years.

Maximum number of benign lesions were seen in the age group of 31 - 50 years. Borderline lesions were seen in the age group between 51 - 60 years and malignant lesions were seen in all age groups except for $51-60$ years.

\section{Ovarian Lesions in Reproductive Age Group and Pregnancy}

All women with history of menstruation were included in reproductive age group. Out of total 142 cases, 98 were in the reproductive age group.

In one case which was operated in pregnancy, the ovary was found to have a serous cyst. The remaining 97 cases were lesions in women in their reproductive period.
Ovarian Lesions in Oral Contraceptive Pill Users and Tubectomised Patients

In our study, more than $90 \%$ of patients were on oral contraceptive pills or had undergone tubectomy at the time of admission. Out of the 98 non-neoplastic lesions, 95.9\% were using oral contraceptive pills earlier and $94.89 \%$ had undergone tubectomy. Out of 42 benign lesions, $85.71 \%$ were using oral contraceptive pills and $83.33 \%$ had undergone tubectomy. Among borderline malignancies out of the two cases one had no history of adopting any family planning methods, while the other had undergone tubectomy. Out of the 6 malignant lesions, $66.66 \%$ were on oral contraceptive pills and $83.33 \%$ had undergone tubectomy.

\section{Unilateral/Bilateral Presentation}

All neoplastic lesions were unilateral except for 3 cases of benign serous cystadenoma, which were bilateral.

\section{Nature of Non-Neoplastic Lesions}

There were lesions, 98 non-neoplastic lesions out of which majority of them were cystic.

\section{Cell of Origin of Neoplastic Lesions}

Ovarian tumours according to the cell of origin are shown in Table 1.

\begin{tabular}{|c|c|c|c|c|}
\hline \multirow{2}{*}{ Sl. } & \multirow{2}{*}{ Nooplastic } & \multicolumn{3}{|c|}{ Cell of Origin of Tumours } \\
\cline { 3 - 5 } & Lesion & $\begin{array}{c}\text { Surface } \\
\text { Epithelial }\end{array}$ & $\begin{array}{c}\text { Sex Cord } \\
\text { Stromal }\end{array}$ & $\begin{array}{c}\text { Germ } \\
\text { Cell }\end{array}$ \\
\hline 1 & Benign & 39 & 1 & 2 \\
\hline 2 & Borderline & 2 & 0 & 0 \\
\hline 3 & Malignant & 4 & 1 & 1 \\
\hline $\mathbf{4}$ & Total & $\mathbf{4 5}$ & $\mathbf{2}$ & $\mathbf{3}$ \\
\hline 5 & Percentage & $90 \%$ & $4 \%$ & $6 \%$ \\
\hline \multicolumn{4}{|c|}{ Table 1. Distribution Pattern based } \\
on Origin of Neoplastic Lesions \\
\hline
\end{tabular}

Distribution of neoplastic lesions based on cell of origin showed $90 \%$ of tumours arising from surface epithelium, $6 \%$ of tumours from germ cell and $4 \%$ of tumours from sex cord stroma.

\section{Prognosis of Malignant Lesion}

All the malignant lesions were graded according to ShimizuSilverberg criteria and are shown in Table 2.

\begin{tabular}{|c|c|c|c|c|c|}
\hline Sl. No. & Lesion & Pattern & Cytologic Atypia & Mitosis & Grade \\
\hline 1 & Well-differentiated mucinous carcinoma & 1 & 2 & 1 & $\mathrm{I}$ \\
\hline 2 & Well-differentiated mucinous cystadenocarcinoma & 1 & 2 & 1 & I \\
\hline 3 & Malignant papillary serous cystadenocarcinoma & 2 & 1 & 2 & I \\
\hline 4 & Serous cystadenocarcinoma & 1 & 2 & 2 & I \\
\hline 5 & Cystadenoma carcinoma & 1 & 2 & 2 & $\mathrm{I}$ \\
\hline 6 & Teratocarcinoma & 3 & 3 & 2 & III \\
\hline
\end{tabular}

In our study, there were six malignant lesions and they were subjected to grading according to Shimizu-Silverberg criteria. Out of six five were under grade I, whereas one was grade III. Grade I has 5-year survival rate for about $90 \%$, whereas grade III has only $40 \%$ chance of 5 -year survival rate.

\section{DISCUSSION}

In the present study, non-neoplastic lesions were more common. Non-neoplastic lesions are important since they may mimic neoplastic lesions and confirmation by histopathological study is mandatory. This helps in distinguishing functional enlargement from neoplasia.[11] In 
concurrence with other studies, we observed that most of the ovarian lesions were found in the reproductive age group.[12,13]

Among non-neoplastic lesions follicular cysts were seen predominantly common and were seen predominantly in the 36 to 45 years' age group, which was concordant with the study of Kanthikar et al.[14] In our study, the percentage of non-neoplastic lesions in 31 to 40 years' and 41 to 50 years' age group was $42.35 \%$ and $43.87 \%$ respectively, making it $86.22 \%$ in 31 to 50 years' age group.

Corpus luteal cysts were stated as the most common nonneoplastic lesions in most of the studies, in which history of OCP was not specified. In our study, it was observed that in patients on OCP there was a decline in the incidence of corpus luteal cyst which is similar to the study done by Vessey M et al.[15] These non-neoplastic lesions although functional are seen in relatively large number of cases, which indicates a possible correlation with the neoplastic lesions later in life. They may influence reproductive course, cause some other malignancies like breast carcinoma or cause obesity and other related non-communicable diseases.[16]

In our study, $87.16 \%$ of lesions were unilateral and $12.83 \%$ were bilateral. It was similar to the study by Verma et al[17] and Madan et al,[18] whereas Kanthikar et al[14] and Bhuvanesh et al[19] showed a higher incidence.

Bilateral lesions were seen in 19 cases, out of which 16 were non-neoplastic. Out of the neoplastic lesions, two were benign and one malignant. It was similar to the study of Parvatala et al.[12]

In an earlier study done by Badge $\mathrm{S} \mathrm{A}$ et al,[20] the age group in which neoplastic lesions occurred were 21 to 30 years followed by 41 to 50 years' age group. In our study, malignant tumours were seen in all age groups except for two cases of borderline malignancies, which were found in the age group of 51 - 60 years. The malignant cases were seen in younger as well as in elderly age, which was concordant with the study by Badge et al. ${ }^{20}$ The borderline group was in $5^{\text {th }}$ decade of life, which was not concurrent with the study by Badge et al.[20] Bhagyalaxmi et al[21] reports an altogether different incidence of age for occurrence of neoplastic lesions in their study.

The neoplastic lesions with an exception of one case were usually seen in multipara, which was similar to the study done by Kanthikar S N et al.[14]

In our study, $90 \%$ of women used OCPs and majority of tumours were non-neoplastic. Use of OCP is considered to be protective in prevention of ovarian malignancies. It could be attributed to reduction in risk of malignancies due to oestrogen as stated by Farghaley[22] and Rice L W[23] in their study.

All the neoplastic lesions were unilateral in our study except for three serous cystadenomas, whereas the study done by Parikh $U$ et al[24] states that malignant tumours were more often bilateral than benign tumours.

A rare case of collision tumour was reported in our study, which showed two components of serous cystadenoma and mature cystic teratoma. There are reported cases of teratoma with cystadenoma or a mucinous cyst. But combination of teratoma with serous cystadenoma is rare and only two reported cases prior to the present case were traceable in the literature.[25] This emphasises the importance of extensive tissue sampling in cystic tumours with thickened capsule. A case of actinomycosis of ovary was reported, which was not suspected preoperatively. On gross examination, it was a solid mass mimicking a malignant lesion, but microscopy revealed actinomycotic colonies. There was no history of intrauterine contraceptive device, but it is an important contributory history associated with actinomycosis.

All non-neoplastic lesions were arising from the Graafian follicle and some from the corpus luteum. The study done by Khan et al[16] also states that the functional ovarian cysts, although non-neoplastic have potential to become tumour or help in the formation of tumour.

In our study, neoplastic lesions as per WHO classification were predominantly of surface epithelial in origin. The malignant as well as the borderline tumours were from surface epithelial origin. Tumours of sex cord stromal and germ cell origin encountered in our study were benign.

\begin{tabular}{|c|c|c|c|}
\hline Origin & $\begin{array}{c}\text { Bhagyalaxmi S } \\
\text { et al (2014) }\end{array}$ & $\begin{array}{c}\text { Kanthikar S N } \\
\text { et al (2014) }\end{array}$ & $\begin{array}{c}\text { Our } \\
\text { Study }\end{array}$ \\
\hline $\begin{array}{c}\text { Surface } \\
\text { epithelial }\end{array}$ & $80.2 \%$ & $65.68 \%$ & $90 \%$ \\
\hline $\begin{array}{c}\text { Sex cord } \\
\text { stromal }\end{array}$ & $4.1 \%$ & $5.7 \%$ & $4 \%$ \\
\hline Germ cell & $14.2 \%$ & $22.84 \%$ & $6 \%$ \\
\hline \multicolumn{3}{|c|}{$\begin{array}{c}\text { Table 3. Comparative Study of Origin } \\
\text { of Malignant Ovarian Lesions }\end{array}$} \\
\hline
\end{tabular}

Grading of ovarian tumours was done based on the latest grading system by Shimizu-Silverberg, which had only three parameters and was easy to follow.[26] Based on this, a grade III teratocarcinoma was reported. All the surface epithelial tumours in the study were grade I. Grading of tumours helps in predicting the survival rate, whereas staging helps in planning the treatment approach for the patient. The interobserver reproducibility was also satisfactory in most of the other studies, which used alternative grading systems like FIGO for comparison.[27]

\section{CONCLUSION}

Non-neoplastic lesions outnumber the neoplastic lesions in the ovary. Among the neoplastic lesions, benign tumours predominate. Pathologist must be vigilant to look out for rare lesions like actinomycosis and collision tumours. Careful grossing is essential, so that lesions embedded in the thickened wall are not missed out.

\section{REFERENCES}

[1] Faller A, Schuenke M, Schuenke G. The human body an introduction to structure and function. New York: Thieme Stuttgart 2004.

[2] Berek JS. Berek and Novak's Gynecology. 15 th edn. Philadelphia: Lippincott Williams and Wilkins 2011.

[3] Yeoh M. Investigation and management of an ovarian mass. Aust Fam Physician 2015;44(1-2):48-52.

[4] Morgan D, Sylvester H, Lucas FL, et al. Cancer prevention and screening practices among women at risk for hereditary breast and ovarian cancer after genetic counseling in the community setting. Fam Cancer 2009;8(4):277-87.

[5] Goldstein CL, Susman E, Lockwood S, et al. Awareness of symptoms and risk factors of ovarian cancer in a population of women and healthcare providers. Clinical Journal of Oncology Nursing 2015;19(2):20612. 
[6] Cunningham FG, Leveno KJ, Bloom SL, et al. Williams Obstetrics. 24th edn. New York: McGraw-Hill Education 2014.

[7] Zolton JR, Maseelall PB. Evaluation of ovarian cysts in adolescents. Open Journal of Obstetrics and Gynecology 2013;3:12-6.

[8] Beretta P, Franchi M, Ghezzi F, et al. Randomized clinical trial of two laparoscopic treatments of endometriomas: cystectomy versus drainage and coagulation. Fertil Steril 1998;70(6):1176-80.

[9] Pal S, Chakrabarti S, Deuoghuria D, et al. Evaluation of ultrasound-guided fine-needle aspiration cytology of ovarian masses with histopathological correlation. Acta Cytologica 2015;59(2):149-55.

[10] Crull JL, Mayer DK, Jessup AN. Early diagnosis, early detection of ovarian cancer. Women's Healthcare. A Clinical Journal for NPs 2014;2:8-31.

[11] Prathima G, Shastry S. Histopathological analysis of neoplastic and non neoplastic lesions of ovary: a study of one hundred cases. Perspectives in Medical Research 2014;2(3):13-17.

[12] Parvatala A, Prasad JR, Rao NB, et al. Study of nonneoplastic lesions of the ovary. IOSR Journal of Dental and Medical Sciences 2015;14(1):92-6.

[13] Forae GD, Aligbe JU. A histopathological overview of ovarian lesions in Benin City, Nigeria. How common are the functional cysts? Int J Med Public Health 2014;4(3):265-8.

[14] Kanthikar SN, Dravid NV, Deore PN, et al. Clinicohistopathological analysis of neoplastic and nonneoplastic lesions of the ovary: a 3-year prospective study in Dhule, North Maharashtra, India. Journal of Clinical and Diagnostic Research 2014;8(8):FC4-FC7.

[15] Vessey M, Metcalfe A, Wells C, et al. Ovarian neoplasms, functional ovarian cysts and oral contraceptives. $\mathrm{Br}$ Med J (Clin Res Ed) 1987;294(6586):1518-20.

[16] Khan N, Afroz N, Aqil B, et al. Neoplastic and nonneoplastic ovarian masses: Diagnosis on cytology. J Cytol 2009;26(4):129-33.
[17] Verma K, Bhatia A. Ovarian neoplasms- A study of 403 tumours. J Obstet Gynaecol India 1981:406-11.

[18] Madan A, Tyagi SP, Mohsin S. Incidence of ovarian tumours at Aligarh with particular reference to histopathological typing. J Obstet Gynecol India 1978:827-32.

[19] Bhuvanesh U, Logambal A. Study of ovarian tumours. J Obstet Gynaecol India 1978;28:271-7.

[20] Badge SA, Gosavi AV, Sulhyan KR. Histopathological study of ovarian tumors. Indian Medical Gazette 2013:345-51.

[21] Bhagyalakshmi A, Sreelekha A, Sridevi S, et al. A prospective study of histopathological patterns of ovarian tumours in a tertiary care centre. Int J Res Med Sci 2014;2(2):448-56.

[22] Farghaly SA. The role of Oral Contraceptive Pills (OCPs) in chemoprevention of epithelial ovarian cancer in women with mutant BRCA1 and BRCA2 genes. J Cancer Sci Ther 2013;5(8):1000-e124. doi:10.4172/1948-5956.1000e124.

[23] Rice LW. Hormone prevention strategies for breast, endometrial and ovarian cancers. Gynecol Oncol 2010;118(2):202-7.

[24] Parikh U, Panchal N. Histopathological patterns of ovarian tumors. International Journal of Scientific Research 2015;4:335-7.

[25] Choudhary S, Adisesha S. Collision tumors of ovary: a rare phenomenon. Intl $\mathrm{J}$ of Case Reports and Images 2012;3(10):68-70.

[26] Silverberg SG. Histopathologic grading of ovarian carcinoma: a review and proposal. Int J Gynecol Pathol 2000;19(1):7-15.

[27] Yamamoto S, Kasajima A, Takano M, et al. Validation of the histologic grading for ovarian clear cell adenocarcinoma: a retrospective multi-institutional study by the Japan Clear Cell Carcinoma Study Group. Int J Gynecol Pathol 2011;30(2):129-38. 